\title{
Differentiation Potential and Tumorigenic Risk of Rat Bone Marrow Stem Cells Are Affected By Long-Term In Vitro Expansion
}

\author{
Sıçan Kemik Iliği Kök Hücrelerinin Farklılaşma Potansiyeli ve Tümörojenik Riski Uzun Süreli \\ In Vitro Ekspansiyondan Etkilenmektedir
}

\author{
(D) Erdal Karaöz1,2,3, (D) Filiz Tepeköy1,4 \\ 1 istinye University Faculty of Medicine, Department of Histology and Embryology, İstanbul, Turkey \\ 2 istinye University Center for Stem Cell and Tissue Engineering Research and Practice, Istanbul, Turkey \\ ${ }^{3}$ Center for Regenerative Medicine and Stem Cell Research and Manufacturing (LivMedCell), Istanbul, Turkey \\ ${ }^{4}$ Altınbaş University Faculty of Medicine, Department of Histology and Embryology, istanbul, Turkey
}

\section{Abstract}

Objective: Mesenchymal stem cells (MSCs) have the capacity for extensive expansion and adipogenic, osteogenic, chondrogenic, myogenic, and neural differentiation in vitro. The aim of our study was to determine stemness, differentiation potential, telomerase activity, and ultrastructural characteristics of long-term cultured rat bone marrow (rBM)-MSCs.

Materials and Methods: rBM-MSCs from passages 3, 50, and 100 (P3, P50, and P100) were evaluated through immunocytochemistry, reverse transcription-polymerase chain reaction, telomerase activity assays, and electron microscopy.

Results: A dramatic reduction in the levels of myogenic markers actin and myogenin was detected in P100. Osteogenic markers Coll1, osteonectin (Sparc), and osteocalcin as well as neural marker c-Fos and chondrogenic marker Coll2 were significantly reduced in P100 compared to P3 and P50. Osteogenic marker bone morphogenic protein-2 (BMP2) and adipogenic marker peroxisome proliferatoractivated receptor gamma (Ppary) expression was reduced in late passages. The expression of stemness factor Rex-1 was lower in P100, whereas 0ct4 expression was decreased in P50 compared to P3 and P100. Increased telomerase activity was observed in longterm cultured cells, signifying tumorigenic risk. Electron microscopic evaluations revealed ultrastructural changes such as smaller number of organelles and increased amount of autophagic vacuoles in the cytoplasm in long-term cultured rBM-MSCs.

Conclusion: This study suggests that long-term culture of rBMMSCs leads to changes in differentiation potential and increased tumorigenic risk.

Keywords: Bone marrow, Differentiation, Long-term culture, Mesenchymal stromal cells, Stemness, Telomerase

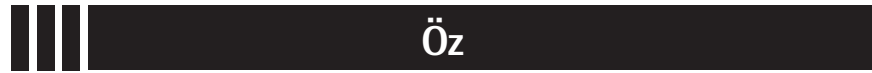

Amaç: Mezenkimal kök hücreler (MKH) in vitro uzun süreli ekspansiyon, adipojenik, osteojenik, kondrojenik, miyojenik ve nöral farklılaşma potansiyeline sahiptir. Çalışmamızın amacı uzun süre kültüre edilen sıçan kemik iliği (sKi)-MKH'lerinin kök hücre niteliklerini, farklılaşma potansiyellerini, telomeraz aktivitelerini ve ultrayapısal özelliklerini belirlemektir.

Gereç ve Yöntemler: 3., 50. ve 100. pasajlardan (P3, P50 ve P100) elde edilen sKi-MKH'leri, immünohistokimya, revers-transkriptaz polimeraz zincir reaksiyonu, telomeraz aktivite analizleri ve elektron mikroskopi ile değerlendirilmiştir.

Bulgular: P100'de miyojenik belirteçlerden aktin ve miyogenin seviyelerinde düşüş gözlemlenmiştir. Osteojenik belirteçler Coll1, osteonektin (Sparc) ve osteokalsin ile nöral belirteç c-Fos ve kondrojenik belirteç Coll2 P100'de P3 ve P50'ye kıyasla önemli ölçüde azalmıştır. Osteojenik belirteç kemik morfojenik protein-2 (BMP2) ve adipojenik belirteç peroksizom proliferatör ile aktive olan reseptör gamma (Ppary) geç pasajlarda düşüş göstermiştir. Kök hücre belirteçlerinden Rex-1'in ekspresyonu P100'de düşüş gösterirken, Oct4 ekspresyonunun P50'de P3 ve $P 100$ 'e göre düşüş gösterdiği belirlenmiştir. Uzun süre kültüre edilen hücrelerdeki artmış telomeraz aktivitesi tumorijenik riske işaret etmektedir. Elektron mikroskopik değerlendirmeler, uzun süre kültüre edilen sKI-MKH sitoplazmasında düşük sayıda organel ve artmış oranda otofajik vaküol gibi utrayapısal değişiklikler ortaya koymuştur.

Sonuç: Bu çalışma, sKi-MKH'lerinin uzun süreli kültüre edilmesinin bu hücrelerin farklılaşma potansiyelinde değişikliklere ve tümörijenik riskin artmasına neden olduğunu göstermiştir.

Anahtar Sözcükler: Kemik iliği, Farklılaşma, Uzun süreli kültür, Mezenkimal kök hücreler, Telomeraz 


\section{Introduction}

Mesenchymal stem cells (MSCs) have the capacity for extensive expansion in vitro and are able to undergo adipogenic, osteogenic, chondrogenic, myogenic, and neural differentiation $[1,2,3]$. MSCs can be obtained from several sources, such as placental tissue [4], amniotic fluid [5], cord blood [6,7], adipose tissue [8,9], and dental pulp [10]. However, bone marrow aspiration remains the source of choice for MSCs in most laboratories $[11,12]$. The secretion of a broad range of bioactive molecules is believed to be the main mechanism by which MSCs achieve their therapeutic effects and these can be divided into eight main categories: immunomodulation, anti-apoptosis, angiogenesis, support of the growth and differentiation of local stem and progenitor cells, anti-scarring, chemoattraction, gene transfer, and exosomes $[13,14,15,16,17,18,19]$.

A sufficient quantity of stem cells can be obtained by in vitro expansion in order to be used in clinical applications [20]. However, during long-term cultures of stem cells, several abnormalities were recorded, such as increased telomerase activity and changes in the expression of genes regarding cell regulation, apoptosis, and senescence due to increased cell doublings and culture times $[21,22,23,24]$. Thus, we proposed that long-term expansion of MSCs in vitro might be associated with tumorigenic risk. MSCs were reported to promote tumor progression and metastasis in a number of studies $[25,26,27,28]$, while other studies suggested that MSCs suppress tumor growth [29,30,31]. Spontaneous transformation was not observed during in vitro expansion of human MSCs (hMSCs) [32,33,34,35]. However, there are reports providing evidence that murine bone marrow (BM)MSCs [36] as well as adipose-derived hMSCs [37] displayed malignant transformation in vitro. It was suggested that the tendency of hMSCs to undergo malignant transformation was caused by the genomic plasticity of undifferentiated hMSCs allowing their longevity [38]. BM-MSCs were also reported to be associated with the in vivo growth of colon cancer, Iymphoma, and melanoma cells $[26,39,40]$. MSCs were found to transform into tumor-associated fibroblasts, constructing a fibrovascular network for the tumors [41]. On the other hand, BM-MSCs were also shown to suppress tumorigenic cells in vivo $[30,42]$.

The aim of the current study was to evaluate long-term (18 months, 100 passages) cultured rat bone marrow (rBM)-MSCs in terms of stemness and differentiation characteristics as well as cell cycle progression and telomerase activity in order to determine their lineage differentiation potential and tumorigenic risk under in vitro conditions.

\section{Materials and Methods}

\section{Isolation and Culture of rBM-MSCs}

The animals (8-week-old male Wistar rats) were anesthetized with Ketalar (Pfizer) and killed by cervical dislocation for rBMMSC isolation. Animal housing and experiments were approved by the local animal care committee (Kocaeli University, HAEK/334) according to the institutional guidelines and national animal welfare standards. rBM-MSCs were obtained from both femurs and tibias of the rats as described in our previous study [43].

For each passage the cells were plated similarly and grown to confluency of 70\%. Passages were performed until 100 passages and the below-mentioned analyses were performed for passages 3,50 , and 100 .

\section{Immunocytochemistry and Immunofluorescence Staining}

The streptavidin-peroxidase method (UltraVision Plus Large Volume Detection System Anti-Polyvalent, HRP Immunostaining Kit, Thermo Scientific, UK) was used for immunocytochemistry analysis as described previously [10]. Immunofluorescence staining was applied as indicated in our previous study [10]. The primary antibodies listed in Table 1 were used for immunocytochemistry and immunofluorescence stainings.

\section{Reverse Transcription-Polymerase Chain Reaction (RT-PCR)}

Total RNA was isolated from rBM-MSCs (passages 3, 100, and 150) according to the manufacturer's instructions (OIAGEN,

\begin{tabular}{|c|c|c|}
\hline Antibody/Marker & Dilution & Source \\
\hline Collagen la1 (D-13) & $1: 50$ & $\begin{array}{l}\text { Santa Cruz } \\
\text { Biotechnology }\end{array}$ \\
\hline Collagen II Ab-2 (2B1.5) & Prediluted & Thermo Scientific \\
\hline Myosin Ila (A4.74) & $1: 50$ & $\begin{array}{l}\text { Santa Cruz } \\
\text { Biotechnology }\end{array}$ \\
\hline Myogenin Ab-1 (F5D) & Prediluted & Thermo Scientific \\
\hline Osteonectin (SPARC) & $1: 50$ & $\begin{array}{l}\text { Chemicon } \\
\text { International }\end{array}$ \\
\hline Osteocalcin (FL-100) & $1: 50$ & $\begin{array}{l}\text { Santa Cruz } \\
\text { Biotechnology }\end{array}$ \\
\hline$\alpha$-Smooth muscle actin Ab- 1 & $1: 800$ & Thermo Scientific \\
\hline Actin (C-2) & $1: 50$ & $\begin{array}{l}\text { Santa Cruz } \\
\text { Biotechnology }\end{array}$ \\
\hline c-Fos (4) & $1: 50$ & $\begin{array}{l}\text { Santa Cruz } \\
\text { Biotechnology }\end{array}$ \\
\hline Tropomyosin (CH1) & $1: 50$ & $\begin{array}{l}\text { Santa Cruz } \\
\text { Biotechnology }\end{array}$ \\
\hline Vimentin (C-20) & $1: 100$ & $\begin{array}{l}\text { Santa Cruz } \\
\text { Biotechnology }\end{array}$ \\
\hline Cytokeratin 19 (CK 19) & $1: 50$ & $\begin{array}{l}\text { Santa Cruz } \\
\text { Biotechnology }\end{array}$ \\
\hline
\end{tabular}


USA). RT-PCR analysis was performed as described in our previous study [44] and bands were quantified using NIH image analysis software (ImageJ Version 1.36b, National Institutes of Health, Bethesda, MD, USA) as described previously [45].

\section{Telomerase Activity}

Telomerase activity was detected by applying a conventional telomeric repeat amplification protocol (TRAP) using the TRAP TeloTAGGG PCR enzyme-linked immunosorbent assay kit (Roche, Mannheim, Germany). The TRAP method was applied as described previously [46].

\section{Electron Microscopy}

rBM-MSCs at passages 3, 50, and 100 were prepared for electron microscopic analysis. The samples were fixed and embedded as described previously [47]. Ultrathin sections were observed with a transmission electron microscope (Carl Zeiss Libra 120).

\section{Statistical Analysis}

The data obtained from ImageJ for RT-PCR bands were analyzed with non-parametric ANOVA on ranks (Kruskal-Wallis test) and parametric one-way ANOVA (Holm-Sidak method). The values are presented as mean \pm SEM. Statistical calculations were performed using Sigma Stat for Windows, version 3.0 (Jandel Scientific Corp., San Rafael, CA, USA). Statistical significance was defined as $p<0.05$.

\section{Results}

\section{Immunolocalization of Differentiation Markers in Long-Term Cultured rBM-MSCs}

Immunocytochemistry analysis in the current study showed that levels of particular myogenic markers including a-SMA and tropomyosin remained similar both in early and late passages. There was a dramatic reduction in actin, myosin $\mathrm{Ila}$, and myogenin levels in passage 100 when compared to passages 3 and 50. Osteogenic markers including Coll1, osteonectin, and osteocalcin as well as neural marker c-Fos and chondrogenic marker Coll2 were reduced in passage 100 compared to passages 3 and 50 (Figure 1; Table 2).

Immunofluorescence analysis revealed that expression of epithelial marker CK-19 was increased after passage 70, while expression of mesenchymal marker vimentin was decreased after passage 70 when compared to passage 3 (Figure 2).

\section{Gene Expression Profiles of Long-Term Cultured rBM-MSCs}

The expressions of the stemness factors as well as adipogenic, chondrogenic, osteogenic, myogenic, and neural differentiation markers were detected in long-term cultured rBM-MSCs by RTPCR analysis using specific primer sets (Table 3).
The expressions of stemness factors Rex-1 and 0ct4 were identified in rBM-MSCs in all passages (P3, P50, and P100). Rex1 expression level was increased in P50 and was decreased in P100 to a lower level than in P3. Oct4 was decreased in P50 compared to P3. Although it was found to be increased in P100, its expression in P100 was lower than in P3. Chondrogenic marker Sox9 was expressed in both early and late passages, and its expression was increased in P50 and significantly decreased in P100. The expressions of differentiation markers of precursor osteoblasts such as osteopontin (Opn/Ssp1), runrelated transcription factor 2 (Runx2), and osteonectin (Sparc) were increased in P50 and were significantly reduced in P100. BMP2 was detected to be expressed at significantly lower levels both in P50 and P100 compared to P3, whereas the BMP4 level was lower only in P50.

Expression of the adipogenic marker Ppary was decreased in P100 compared to P3 and P50. Adiponectin and monoglyceride lipase (MgLL) expressions were detected to be similar in all passages. ADFP was expressed in all three passages, with a higher level in P50. Neurofilament heavy chain (NF-H) and glial fibrillary acidic protein (GFAP) expressions were higher in P50 compared to P3 while they were decreased in P100. Neuroprogenitor cell marker $\beta 3$-tubulin (TUBB3) was significantly decreased in P100 compared to P3 and P50. Another neuroprogenitor cell marker, gamma enolase (Eno2), was increased in P50 and reduced in P100 compared to P50. Precursor myoblast markers $\alpha$-smooth muscle actin (Acta2) and ActB were increased in P50 and decreased in P100, whereas desmin (Des) and myogenin (Myog) expression levels were similar in all passages (Figure 3).

\section{Telomerase Activity}

Relative telomerase activities (RTAs) of rBM-MSCs (P3, P50, and P150) were measured and the calculations were normalized to $1 \mu \mathrm{g}$ of total protein equivalent. The results for rBM-MSCs at

\begin{tabular}{|l|l|l|l|}
\hline \multicolumn{4}{|l|}{ Table 2. Immunocytochemical properties of rBM-MSCs. } \\
\hline & $\begin{array}{l}\text { rBM- } \\
\text { MSCs }\end{array}$ & & \\
\hline Antibody/Marker & P3 & P50 & P100 \\
\hline $\boldsymbol{\alpha}-$ SMA & + & + & + \\
\hline Actin & + & + & $\emptyset$ \\
\hline Collagen type I & + & $-/+$ & $\emptyset$ \\
\hline Collagen type II & + & + & $\emptyset$ \\
\hline c-Fos & + & + & $-/+$ \\
\hline Osteocalcin & + & + & $-/+$ \\
\hline Osteonectin (SPARC) & + & + & $-/+$ \\
\hline Myosin Ila & + & $-/+$ & $-/+$ \\
\hline Myogenin & + & $-/+$ & $\emptyset$ \\
\hline Tropomyosin & + & + & + \\
\hline $\begin{array}{l}\text { +: Positive marker expression. -l+: Weak marker expression. Ø: Lack of marker } \\
\text { expression, rBM-MSCs: Rat bone marrow mesenchymal stem cells. }\end{array}$ \\
\hline
\end{tabular}


passages 3, 50, and 100 were found as 8.4, 19.89, and 45.09 RTA/ $\mu \mathrm{g}$ total protein, respectively. According to these data, rBM-MSCs at later passages show a higher rate of telomerase activity (Figure 4).

\section{Ultrastructural Characteristics}

rBM-MSCs from both early and late passages showed pale, eccentric, irregularly shaped, and large euchromatic nuclei with one or more nucleoli located near the perinuclear cisternae. The cell cytoplasms from passage 3 had an intensely stained inner zone rich in elongated mitochondria and rough endoplasmic reticulum ( $r E R$ ) cisternae and a relatively peripheral zone poor in organelles. The rER cisternae were dilated and contained moderately electron-dense material. Aggregates of a few lipid droplets, granules, and glycogen were also observed. Numerous thin pseudopodia were observed on the cell surfaces. rBM-MSCs from late passages contained a smaller number of organelles and increased amount of pseudopodia on the cell surfaces. Empty vacuoles in the cytoplasm were observed to be increased in rBM-MSCs from late passages with respect to early passages. Free ribosomes were observed in the cytoplasms of cells from both early and late passages. These results constitute the first comparative and comprehensive detailed report of ultrastructural characteristics on long term cultured rBM-MSCs (Figure 5).

\section{Discussion}

There are conflicting results in the literature regarding malignant transformation of MSCs during in vitro culture. A number of reports proved the transformation of these cells $[38,48,49,50]$, whereas certain studies found a relation with aneuploidy [51,52,53,54] and genetic mutations [55] while other studies suggested that these cells do not undergo transformation after long-term expansion [34]. In the current study we performed long-term, non-stop culture of rBM-MSCs for 18 months including 100 passages. These long-term cultured cells were examined for stemness factors as well as myogenic, chondrogenic, adipogenic, osteogenic, and neurogenic differentiation markers; epithelial and mesenchymal cell markers; telomerase activity; and ultrastructural characteristics. Interestingly, these cells showed higher expressions of CK-19 and lower expressions of vimentin after passage 70, signifying mesenchymal-to-epithelial transition in late passages. Previous studies regarding long-term culture of hMSCs also identified transformation of spindle-shaped cells into round epithelial-
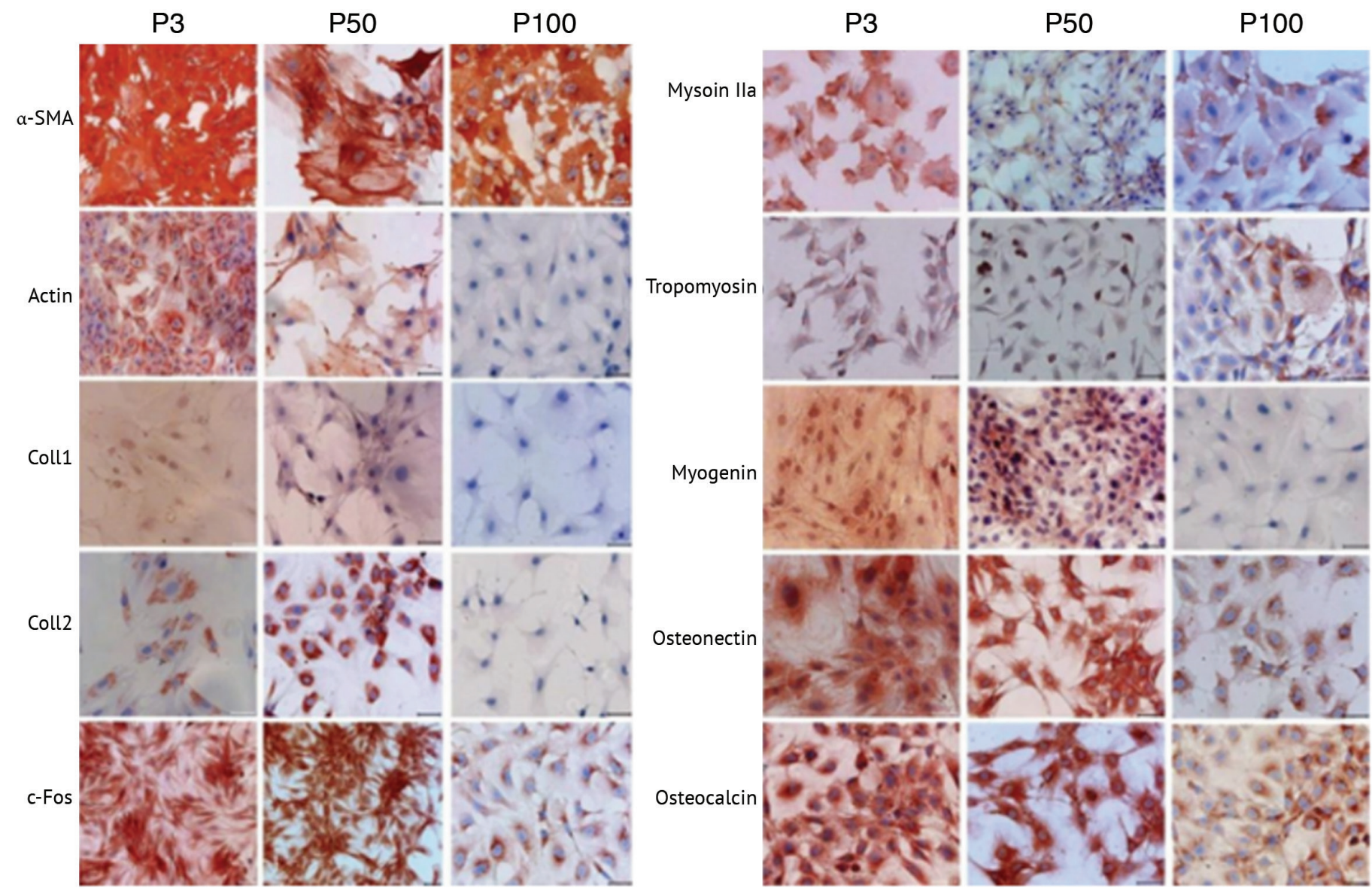

Figure 1. Lineage differentiation marker localizations in cultured rat bone marrow mesenchymal stem cells. P3: Passage 3. P50: Passage 50. P100: Passage 100. Nuclei were counterstained with hematoxylin. All experiments were repeated 3 times. Scale bars: $50 \mu \mathrm{m}$. 
like cells that had an increased nucleus-to-cytoplasm ratio [38]. In previous studies it was shown that long-term cultures of both human [56] and rabbit [57] MSCs resulted in cellular senescence. Long-term expanded senescent cells were shown to have reduced differentiation potential, which led to restriction in MSC expansion for therapeutic applications [56,58,59].

\begin{tabular}{|c|c|c|c|}
\hline Gene & Primer Sequence & GenBank & Product \\
\hline & & Acc. No. & Size (bp) \\
\hline ACTA2 & F: ATGAGGGCTATGCCTTGCCC & NM_001613 & 307 \\
\hline Smooth muscle actin & R: CCCGATGAAGGATGGCTGGA & & \\
\hline ACTB & F: TGGCACCACACCTCTACAATGAGC & NM_001101 & 395 \\
\hline Actin beta & R: GCACAGCTTCTCCTTAATGTCACGC & & \\
\hline ADIPOQ & F: ATGGTCCTGTGATGCTITGA & NM_004797 & 229 \\
\hline Adiponectin & R: GTGAGTGCGTATGTATITा & & \\
\hline BMP2 & F: GTGCTTCTAGACGGACTGC & NM_001200 & 1,232 \\
\hline Bone morphogenetic & R: GTACTAGCGACACCCACAAC & & \\
\hline \multicolumn{4}{|l|}{ protein 2} \\
\hline BMP4 & F: AGCCATTCCGTAGTGCCATC & NM_130851 & 1,374 \\
\hline Bone morphogenetic & R: AAGGACTGCCTGATCTCAGC & & \\
\hline \multicolumn{4}{|l|}{ protein 4} \\
\hline$D E S$ & F: CAGGTGGAGATGGACATGTCTAAGC & NM_001927 & 186 \\
\hline Desmin & R: TCATCTCCTGCTTGGCCTGG & & \\
\hline ENO2 & F: TATGGGCATGGATGTGGCTGC & NM_001975 & 269 \\
\hline Enolase 2, gamma & R: CCCGCTCAATACGTITGGG & & \\
\hline GFAP & F: TCCTCAGGGGAGATGATGGT & NM_0011310 & 211 \\
\hline Glial fibrillary acidic protein & R: TCTCGATGTAGCTGGCAAAG & 19 & \\
\hline MGLL & F: CAATCCTGAATCTGCAACAACTTC & NM_007283 & 411 \\
\hline Monoglyceride lipase & R: ATGTTATTCATGGAAGACGGAGT & & \\
\hline MYOG & F: TATGAGACATCCCCCTACTTCTACC & NM_002479 & 279 \\
\hline Myogenin & R: CПTCTGAGCCTGCGCTCT & & \\
\hline NEF-H & F: GAACACAGACGCTATGCGCTCAG & NM_021076 & 396 \\
\hline Neurofilament, heavy & R: CACCITATGTGAGTGGACACAGAG & & \\
\hline \multirow[t]{2}{*}{ OCT4/POU5F1 } & F: TGCCGTGAAACTGAAGAAG & NM_203289 & 72 \\
\hline & R: TTCTGCAGAGCTTTGATGTC & & \\
\hline OPN/SPP1 & F: CAGTGACCAGTCATCAGATCATC & NM_0010400 & 374 \\
\hline Osteopontin & R: CTAGGCATCACCTGTGCCATACC & 58 & \\
\hline PLIN2 & F: CGCTGTCACTGGGGCAAAAGA & NM_001122 & 173 \\
\hline Adipophilin & R: ATCCGACTCCCCAAGACTGTGTTA & & \\
\hline $\begin{array}{l}\text { Peroxisome proliferator-activated receptor } \\
\text { gamma }\end{array}$ & $\begin{array}{l}\text { F: CAGTGGGGATGCTCATAA } \\
\text { R: CIIIGGCATACTCTGTGAT }\end{array}$ & NM_138711 & 422 \\
\hline \multirow[t]{2}{*}{ REX-1/ZFP42 } & $\begin{array}{l}\text { F: GGATCTCCCACCTTTCCAAG } \\
\text { R: GCAGGTAGCACACCTCCTG }\end{array}$ & & \\
\hline & F: GGATCTCCСАССТTCCAAG & NM_020695 & 104 \\
\hline $\begin{array}{l}\text { RUNX2 } \\
\text { Runt-related transcription factor } 2\end{array}$ & $\begin{array}{l}\text { F: CAGACCAGCAGCACTCCATA } \\
\text { R: CAGCGTCAACACCATCATC }\end{array}$ & NM_004348 & 177 \\
\hline $\begin{array}{l}\text { SOX9 } \\
\text { SRY-box } 9\end{array}$ & $\begin{array}{l}\text { F: TGAAGAAGGAGAGCGAGGAA } \\
\text { R: GGGGCTGGTACTTGTAATCG }\end{array}$ & NM_000346 & 348 \\
\hline $\begin{array}{l}\text { SPARC } \\
\text { Osteonectin }\end{array}$ & $\begin{array}{l}\text { F: TCTTCCCTGTACACTGGCAGTTC } \\
\text { R: AGCTCGGTGTGGGAGAGGTA }\end{array}$ & NM_003118 & 73 \\
\hline $\begin{array}{l}\text { TUBB3 } \\
\text { Tubulin, beta } 3\end{array}$ & $\begin{array}{l}\text { F: CATGGACAGTGTCCGCTCAG } \\
\text { R: CAGGCAGTCGCAGTITCAC }\end{array}$ & NM_006086 & 175 \\
\hline
\end{tabular}


Though we have found that rBM-MSCs preserve stemness factors even in late passages, they lack particular differentiation markers after long-term culture, highlighting their limited differentiation potential.

As an indication of the reduced adipogenic differentiation capacity of rBM-MSCs during long-term culture, in the current study we detected that expression of adipogenic marker PPAR-c was significantly decreased in late passages. PPAR-c is known to induce adipogenesis [60]. PPAR-c suppression was detected to cause generation of osteoblasts rather than adipocytes from BM progenitors [61]. After long-term in vitro expansion, although BM-MSCs were unable to display adipogenic differentiation, they were shown to have osteogenic differentiation potential [58].

Furthermore, it was also shown that osteogenic differentiation potential does not depend on the age of the donor [62]. In our study, expression levels of most of the osteogenic markers, including BMP-2, were significantly reduced during longterm culture. Coll1, osteonectin, osteocalcin, and Runx2 were detected to be reduced, especially in P100. Additionally, a dramatic reduction in chondrogenic marker SOX9 levels was detected, as well as a decrease in Coll2 levels in late passages.
Thus, our results including in vitro expanded stem cells showed that the osteogenic and chondrogenic potential of long-term cultured stem cells might be disrupted. In previous studies, it was reported that human adipose-derived stem cells were able to differentiate into osteogenic cells, but this ability was reduced after long-term in vitro expansion [63].

The level of neural marker TUBB3 was gradually reduced in late passages and was detected to be significantly lower in P100. The c-Fos level was also decreased in P100. Although NF-H and GFAP levels were increased in P50, they were detected to be reduced in $\mathrm{P} 100$. Thus, the data obtained in this study indicate that the neurogenic differentiation potential of rBM-MSCs might be affected by long-term culture. Particular myogenic differentiation markers including myogenin and desmin were detected to be expressed in low levels both in early and late passages, whereas myogenin was found to be reduced during the late passages. Levels of a-SMA and tropomyosin were also detected to be similar in both early and late passages. However, myogenic markers ACTa, ACTb, and myosin Ila were detected to be reduced in $\mathrm{P} 100$. These results indicate that, in order to evaluate the lineage differentiation of stem cells, particular markers should be assessed in terms of both gene and protein levels.
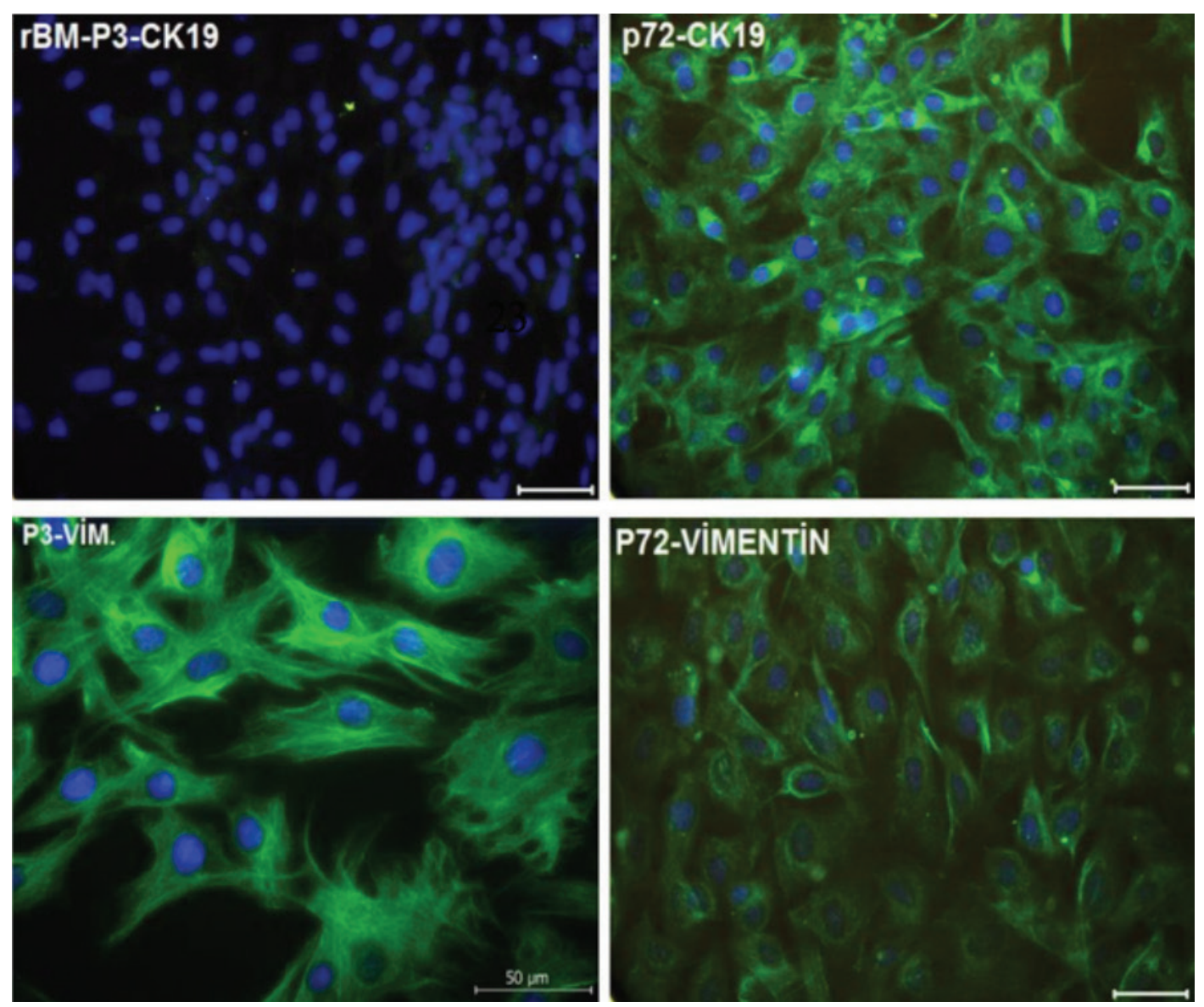

Figure 2. Localizations of cytokeratin 19 (green) and vimentin (green) in cultured rat bone marrow mesenchymal stem cells. P3: Passage 3. P72: Passage 72. Nuclei were labeled with DAPI (blue). All experiments were repeated 3 times. Scale bars: $50 \mu m$. 


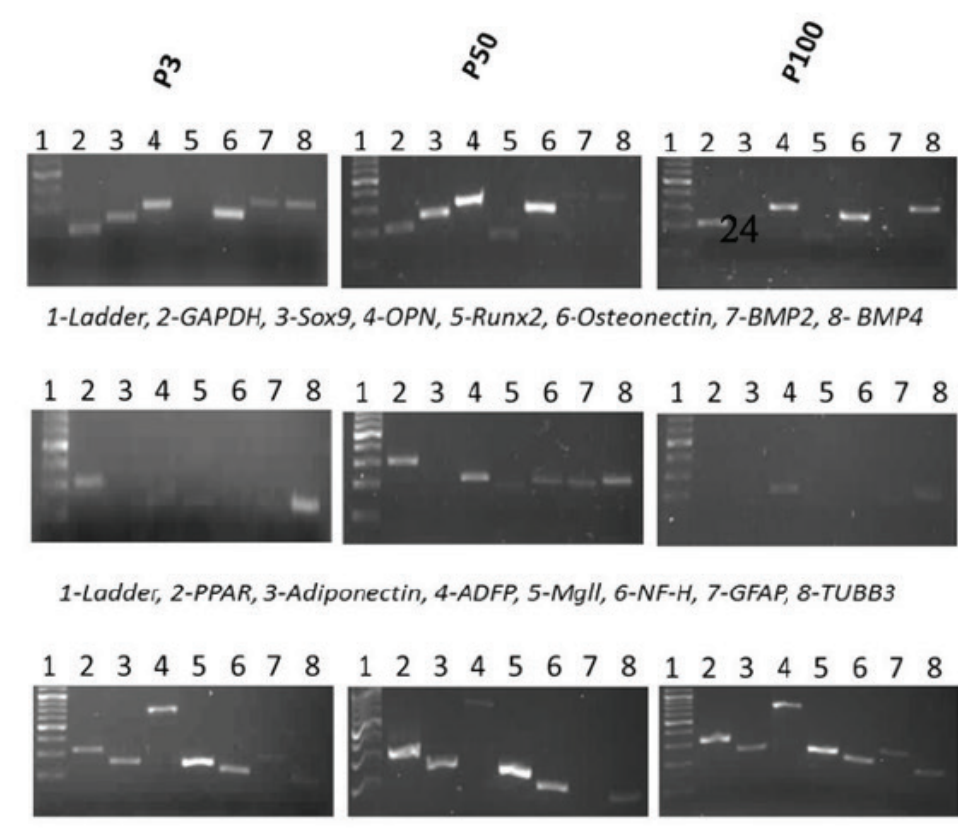

1-Ladder, 2-Enolase, 3-Rex-1, 4-OCT4, 5-ACTA, 6-ACTB, 7-Myogenin, 8-Desmin

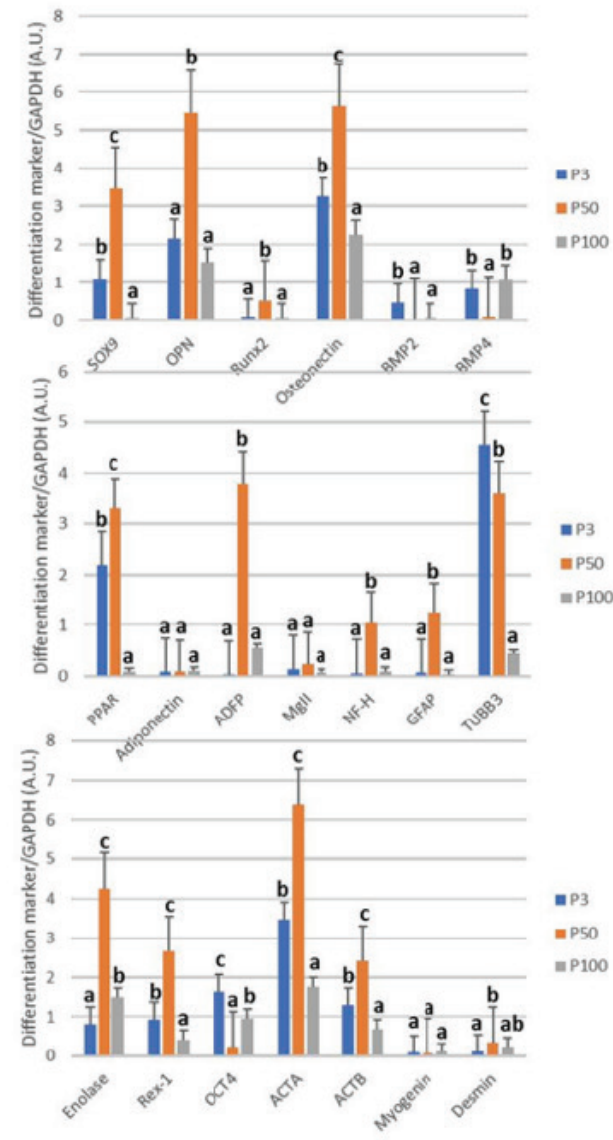

Figure 3. Reverse transcription-polymerase chain reaction bands and graphics of mathematical values of Image evaluations of embryonic stem cell (Rex-1 and Oct4) and differentiation (Sox-9, osteopontin, Runx2, osteonectin [SPARC], BMP-2, BMP-4, PPAR, adiponectin, ADFP, Mgll, NF-H, GFAP, TUBB3, Eno2, ACTA, ACTB, myogenin, and desmin) markers in cultured rat bone marrow mesenchymal stem cells. Values are presented as mean \pm SEM. Different letters mark statistical significance $(p<0.05)$ (one-way ANOVA, Holm-Sidak method). P3: Passage 3. P50: Passage 50. P100: Passage 100. All experiments were repeated 3 times.

\section{Telomerase activity of rBM-MSCs}

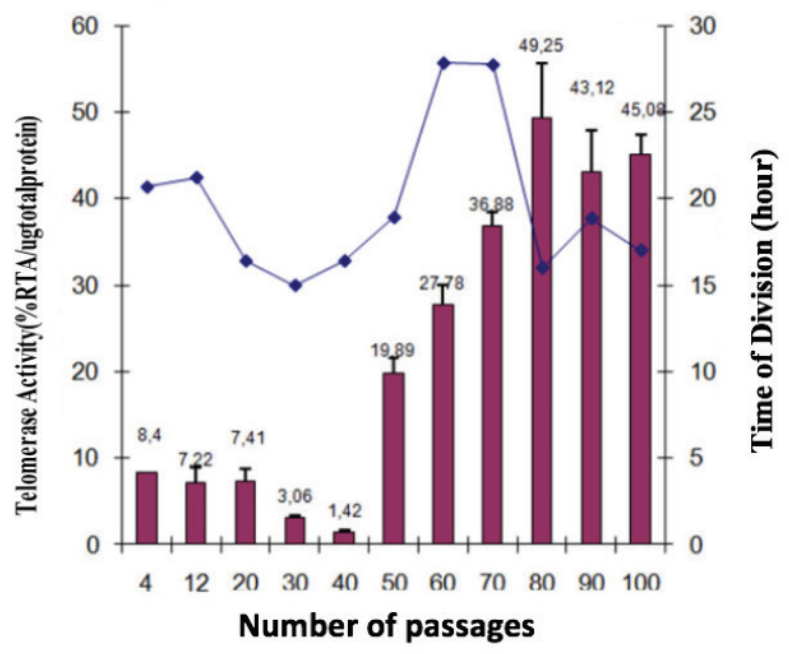

telomerase activity $\bullet$ DT

Figure 4. Telomerase activity assessment of cultured rat bone marrow mesenchymal stem cells. Values are presented as mean \pm SEM. All experiments were repeated 3 times.
Autophagy has been shown to effect the inhibition of continuous growth of precancerous cells and suppression of cancer [64]. As reviewed by Kocaturk et al. [65], autophagy leads to the removal of damaged macromolecules or organelles, such as mitochondria [66], ER [67], ribosomes [68], and lipid droplets [69]. We have also revealed ultrastructural changes in BM-MSCs at late passages, including a smaller number of organelles as well as a high number of autophagic vacuoles in the cytoplasm, which might be an indication of tumorigenic cells with increased rates of autophagy. Telomere length displays the proliferative potential of somatic cells [70]. Telomerase activity levels and telomere lengths were investigated in order to examine the safety of long-term cultured hMSCs in previous studies $[56,71]$. There are conflicting reports regarding the telomerase activity of these cells. It was shown that telomerase activity in hMSCs during long-term culture was not altered and remained at a very low level, and telomere lengths of hMSCs were remarkably decreased at late passages [71], while other studies showed that the telomerase activity of cultured hMSCs decreased and these cells displayed telomere shortening during serial passaging 

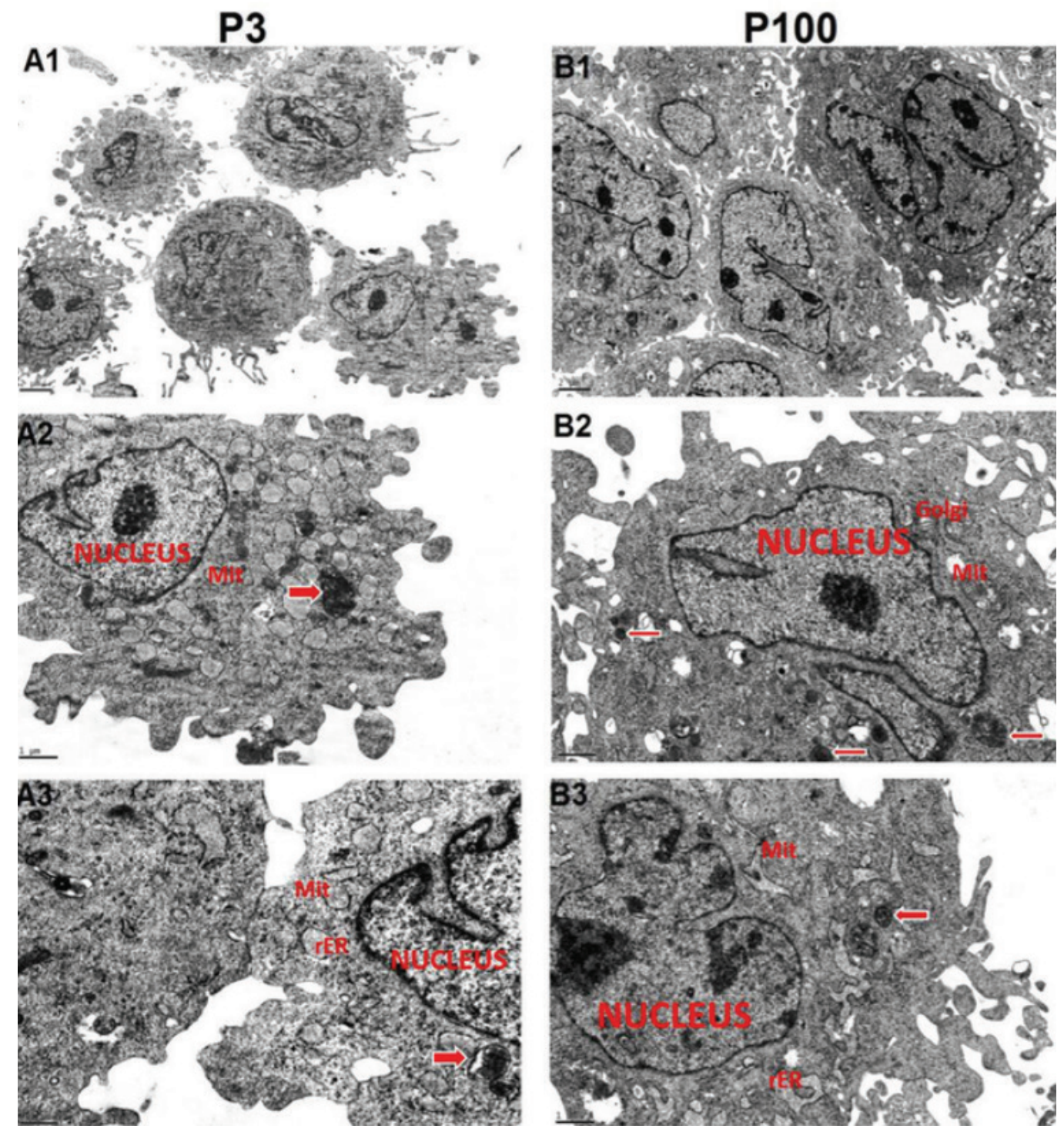

Figure 5. Electron micrographs of cultured rat bone marrow mesenchymal stem cells. P3: Passage 3. P100: Passage 100. Rough endoplasmic reticulum (rER), mitochondria (Mit), Golgi apparatus (Golgi), and autophagic vacuoles (arrows) are marked. All experiments were repeated 3 times.

$[56,72,73]$. Some reports revealed senescence in the culture ultimately [55]. However, in our study, we have found increased telomerase activity of BM-MSCs in late passages, consistent with particular reports revealing several abnormalities in long-term cultured MSCs including increased telomerase activity [21,22].

Rodent BM-MSCs and hMSCs have displayed some common surface antigens such as CD29, CD90, and CD105, used for MSC characterization [74]. Gene expression profiling of MSCs from rodents has revealed a high degree of concordance with hMSCs [75]. The changes in gene expressions and protein levels of rBM-MSCs during long-term culture might also be possible for hMSCs and we believe that for clinical applications following long-term culture of these cells, data obtained from both humans and rodents must be considered.

\section{Conclusion}

The data obtained from this study reveal that long-term culture of rBM-MSCs leads to changes in the MSC characteristics of these cells as well as increased tumorigenic risk via increased telomerase activity. In order to provide efficiency of differentiation potential and safety regarding tumor formation risk of cultured MSCs for cellular therapy, further phenotypic and functional investigations as well as genetic characterizations of MSCs must be conducted.

\section{Acknowledgments}

The authors would like to thank Alparslan Okcu, Cansu Subaşı, and Gökhan Duruksu for their technical assistance and Figen Kaymaz for her contribution in electron microscopy analysis. This study was supported by the Scientific Research Projects Coordination Unit of Kocaeli University. 


\section{Ethics}

Ethics Committee Approval: Animal housing and experiments were approved by the local animal care committee (Kocaeli University, HAEK/33-4) according to the institutional guidelines and national animal welfare standards.

\section{Authorship Contributions}

Surgical and Medical Practices: E.K.; Concept: E.K.; Design: E.K.; Data Collection or Processing: E.K., F.T.; Analysis or Interpretation: E.K., F.T.; Literature Search: E.K., F.T.; Writing: E.K., F.T.

Conflict of Interest: The authors of this paper have no conflicts of interest, including specific financial interests, relationships, and/or affiliations relevant to the subject matter or materials included.

Financial Disclosure: This study was supported by the Scientific Research Projects Coordination Unit of Kocaeli University.

\section{References}

1. Czyz J, Wiese C, Rolletschek A, Blyszczuk P, Cross M, Wobus AM. Potential of embryonic and adult stem cells in vitro. Biol Chem 2003;384:13911409.

2. Pittenger MF, Mackay AM, Beck SC, Jaiswal RK, Douglas R, Mosca JD, Moorman MA, Simonetti DW, Craig S, Marshak DR. Multilineage potential of adult human mesenchymal stem cells. Science 1999;284:143-147.

3. Woodbury D, Schwarz EJ, Prockop DJ, Black IB. Adult rat and human bone marrow stromal cells differentiate into neurons. J Neurosci Res 2000;61:364-370.

4. Zhang $X$, Nakaoka $T$, Nishishita $T$, Watanabe $N$, Igura $K$, Shinomiya $K$, Takahashi TA, Yamashita N. Efficient adeno-associated virus-mediated gene expression in human placenta-derived mesenchymal cells. Microbiol Immunol 2003;47:109-116.

5. Harrell CR, Gazdic M, Fellabaum C, Jovicic N, Djonov V, Arsenijevic N, Volarevic V. Therapeutic potential of amniotic fluid derived mesenchymal stem cells based on their differentiation capacity and immunomodulatory properties. Curr Stem Cell Res Ther 2019;14:327-336.

6. Najar M, Crompot E, van Grunsven LA, Dollé L, Lagneaux L. Aldehyde dehydrogenase activity of Wharton jelly mesenchymal stromal cells: isolation and characterization. Cytotechnology 2019;71:427-441.

7. Karaöz E, Çetinalp Demircan $P$, Erman G, Güngörürler E, Eker Sarıboyacı A. Comparative analyses of immunosuppressive characteristics of bonemarrow, Wharton's jelly, and adipose tissue-derived human mesenchymal stem cells. Turk J Hematol 2017;34:213-225.

8. Al-Jezani N, Cho R, Masson AO, Lenehan B, Krawetz R, Lyons FG. Isolation and characterization of an adult stem cell population from human epidural fat. Stem Cells Int 2019;2019:2175273.

9. Karaoz E, Okcu A, Ünal ZS, Subasi C, Saglam O, Duruksu G. Adipose tissuederived mesenchymal stromal cells efficiently differentiate into insulinproducing cells in pancreatic islet microenvironment both in vitro and in vivo. Cytotherapy 2013;15:557-570.

10. Karaöz E, Demircan PC, Sağlam O, Aksoy A, Kaymaz F, Duruksu G. Human dental pulp stem cells demonstrate better neural and epithelial stem cell properties than bone marrow-derived mesenchymal stem cells. Histochem Cell Biol 2011;136:455-473.

11. Le Blanc K, Pittenger M. Mesenchymal stem cells: progress toward promise. Cytotherapy 2005;7:36-45.
12. Karaöz E, Okçu A, Gacar G, Sağlam O, Yürüker S, Kenar H. A comprehensive characterization study of human bone marrow MSCs with an emphasis on molecular and ultrastructural properties. J Cell Physiol 2011;226:13671382.

13. Skolekova S, Matuskova M, Bohac M, Toro L, Durinikova E, Tyciakova S, Demkova L, Gursky J, Kucerova L. Cisplatin-induced mesenchymal stromal cells-mediated mechanism contributing to decreased antitumor effect in breast cancer cells. Cell Commun Signal 2016;14:4.

14. Hu MS, Leavitt T, Malhotra $S$, Duscher D, Pollhammer MS, Walmsley GG, Maan ZN, Cheung AT, Schmidt M, Huemer GM, Longaker MT, Lorenz HP. Stem cell-based therapeutics to improve wound healing. Plast Surg Int 2015;2015:383581.

15. Guan LX, Guan H, Li HB, Ren CA, Liu L, Chu JJ, Dai L. Therapeutic efficacy of umbilical cord-derived mesenchymal stem cells in patients with type 2 diabetes. Exp Ther Med 2015;9:1623-1630.

16. Arthur A, Zannettino A, Gronthos S. The therapeutic applications of multipotential mesenchymal/stromal stem cells in skeletal tissue repair. J Cell Physiol 2009;218:237-245.

17. Studeny $M$, Marini $F C$, Dembinski JL, Zompetta $C$, Cabreira-Hansen $M$, Bekele BN, Champlin RE, Andreeff M. Mesenchymal stem cells: potential precursors for tumor stroma and targeted-delivery vehicles for anticancer agents. J Natl Cancer Inst 2004;96:1593-1603.

18. Hamada H, Kobune M, Nakamura K, Kawano Y, Kato K, Honmou O, Houkin $\mathrm{K}$, Matsunaga T, Niitsu Y. Mesenchymal stem cells (MSC) as therapeutic cytoreagents for gene therapy. Cancer Sci 2005;96:149-156.

19. Kordelas L, Rebmann V, Ludwig AK, Radtke S, Ruesing J, Doeppner TR, Epple M, Horn PA, Beelen DW, Giebel B. MSC-derived exosomes: a novel tool to treat therapy-refractory graft-versus-host disease. Leukemia 2014;28:970973.

20. Danisovic L, Oravcova L, Krajciova L, Varchulova Novakova Z, Bohac M, Varga I, Vojtassak J. Effect of long-term culture on the biological and morphological characteristics of human adipose tissue-derived stem cells. J Physiol Pharmacol 2017;68:149-158.

21. Sedivy JM. Can ends justify the means?: Telomeres and the mechanisms of replicative senescence and immortalization in mammalian cells. Proc Natl Acad Sci U S A 1998;95:9078-9081.

22. Milyavsky $M$, Shats I, Erez N, Tang $X$, Senderovich $S$, Meerson A, Tabach $Y$, Goldfinger N, Ginsberg D, Harris CC, Rotter V. Prolonged culture of telomerase-immortalized human fibroblasts leads to a premalignant phenotype. Cancer Res 2003;63:7147-7157.

23. Froelich K, Mickler J, Steusloff G, Technau A, Ramos Tirado M, Scherzed A, Hackenberg S, Radeloff A, Hagen R, Kleinsasser N. Chromosomal aberrations and deoxyribonucleic acid single-strand breaks in adiposederived stem cells during long-term expansion in vitro. Cytotherapy 2013;15:767-781.

24. Jiang L, Liu T, Song K. Growth characteristics of human adipose-derived stem cells during long time culture regulated by cyclin a and cyclin D1. Appl Biochem Biotechnol 2012;168:2230-2244.

25. Karnoub $A E$, Dash $A B$, Vo AP, Sullivan $A$, Brooks MW, Bell GW, Richardson AL, Polyak K, Tubo R, Weinberg RA. Mesenchymal stem cells within tumour stroma promote breast cancer metastasis. Nature 2007;449:557-563.

26. Zhu W, Xu W, Jiang R, Qian H, Chen M, Hu J, Cao W, Han C, Chen Y. Mesenchymal stem cells derived from bone marrow favor tumor cell growth in vivo. Exp Mol Pathol 2006;80:267-274.

27. Prantl L, Muehlberg F, Navone NM, Song YH, Vykoukal J, Logothetis CJ, Alt EU. Adipose tissue-derived stem cells promote prostate tumor growth. Prostate 2010;70:1709-1715.

28. Shinagawa K, Kitadai $Y$, Tanaka M, Sumida T, Kodama M, Higashi Y, Tanaka S, Yasui W, Chayama K. Mesenchymal stem cells enhance growth and metastasis of colon cancer. Int J Cancer 2010;127:2323-2333. 
29. Secchiero $P$, Zorzet $S$, Tripodo C, Corallini F, Melloni E, Caruso L, Bosco $\mathrm{R}$, Ingrao $\mathrm{S}$, Zavan $\mathrm{B}$, Zauli G. Human bone marrow mesenchymal stem cells display anti-cancer activity in SCID mice bearing disseminated nonHodgkin's lymphoma xenografts. PLoS One 2010;5:e11140.

30. Otsu K, Das S, Houser SD, Quadri SK, Bhattacharya S, Bhattacharya J. Concentration-dependent inhibition of angiogenesis by mesenchymal stem cells. Blood 2009;113:4197-4205.

31. Cousin B, Ravet E, Poglio S, De Toni F, Bertuzzi M, Lulka H, Touil I, André M, Grolleau JL, Péron JM, Chavoin JP, Bourin P, Pénicaud L, Casteilla L, Buscail $L$, Cordelier P. Adult stromal cells derived from human adipose tissue provoke pancreatic cancer cell death both in vitro and in vivo. PLoS One 2009;4:e6278.

32. Bernardo ME, Zaffaroni $N$, Novara F, Cometa AM, Avanzini MA, Moretta A, Montagna D, Maccario R, Villa R, Daidone MG, Zuffardi O, Locatelli F. Human bone marrow derived mesenchymal stem cells do not undergo transformation after long-term in vitro culture and do not exhibit telomere maintenance mechanisms. Cancer Res 2007;67:9142-9149.

33. Meza-Zepeda LA, Noer A, Dahl JA, Micci F, Myklebost O, Collas P. Highresolution analysis of genetic stability of human adipose tissue stem cells cultured to senescence. J Cell Mol Med 2008;12:553-563.

34. Chen G, Yue A, Ruan Z, Yin Y, Wang R, Ren Y, Zhu L. Human umbilical cordderived mesenchymal stem cells do not undergo malignant transformation during long-term culturing in serum-free medium. PLoS One 2014;9:e98565.

35. Zaman WS, Makpol S, Sathapan S, Chua KH. Long-term in vitro expansion of human adipose-derived stem cells showed low risk of tumourigenicity. J Tissue Eng Regen Med 2014;8:67-76.

36. Miura M, Miura Y, Padilla-Nash HM, Molinolo AA, Fu B, Patel V, Seo BM, Sonoyama W, Zheng JJ, Baker CC, Chen W, Ried T, Shi S. Accumulated chromosomal instability in murine bone marrow mesenchymal stem cells leads to malignant transformation. Stem Cells 2006;24:1095-1103.

37. Mangi AA, Noiseux N, Kong D, He H, Rezvani M, Ingwall JS, Dzau VJ. Mesenchymal stem cells modified with Akt prevent remodeling and restore performance of infarcted hearts. Nat Med 2003;9:1195-1201.

38. Røsland GV, Svendsen A, Torsvik A, Sobala E, McCormack E, Immervoll $H_{\text {, }}$ Mysliwietz J, Tonn JC, Goldbrunner R, Lønning PE, Bjerkvig R, Schichor C. Long-term cultures of bone marrow-derived human mesenchymal stem cells frequently undergo spontaneous malignant transformation. Cancer Res 2009;69:5331-5339.

39. Djouad F, Plence P, Bony C, Tropel P, Apparailly F, Sany J, Noël D, Jorgensen C. Immunosuppressive effect of mesenchymal stem cells favors tumor growth in allogeneic animals. Blood 2003;102:3837-3844.

40. Amé-Thomas P, Maby-El Hajjami H, Monvoisin C, Jean R, Monnier D, CauletMaugendre S, Guillaudeux T, Lamy T, Fest T, Tarte K. Human mesenchymal stem cells isolated from bone marrow and lymphoid organs support tumor B-cell growth: role of stromal cells in follicular lymphoma pathogenesis. Blood 2007;109:693-702.

41. Spaeth E, Dembinski JL, Sasser AK, Watson K, Klopp A, Hall B, Andreeff M, Marini F. Mesenchymal stem cell transition to tumor-associated fibroblasts contributes to fibrovascular network expansion and tumor progression. PLoS One 2009;4:e4992.

42. Ramasamy R, Lam EW, Soeiro I, Tisato V, Bonnet D, Dazzi F. Mesenchymal stem cells inhibit proliferation and apoptosis of tumor cells: impact on in vivo tumor growth. Leukemia 2007;21:304-310.

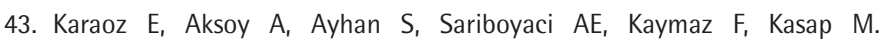
Characterization of mesenchymal stem cells from rat bone marrow: ultrastructural properties, differentiation potential and immunophenotypic markers. Histochem Cell Biol 2009;132:533-546.

44. Karaoz E, Ayhan S, Okçu A, Aksoy A, Bayazıt G, Osman Gürol A, Duruksu G. Bone marrow-derived mesenchymal stem cells co-cultured with pancreatic islets display beta cell plasticity. J Tissue Eng Regen Med 2011;5:491-500.
45. Tepekoy $F$, Ustunel I, Akkoyunlu G. Protein kinase $C$ isoforms $\alpha, \delta$ and $\varepsilon$ are differentially expressed in mouse ovaries at different stages of postnatal development. J Ovarian Res 2014;7:117.

46. Karaoz E, Ayhan S, Gacar G, Aksoy A, Duruksu G, Okçu A, Demircan PC, Sariboyaci $A E$, Kaymaz $F$, Kasap M. Isolation and characterization of stem cells from pancreatic islet: pluripotency, differentiation potential and ultrastructural characteristics. Cytotherapy 2010;12:288-302.

47. Karaöz E, Doğan BN, Aksoy A, Gacar G, Akyüz S, Ayhan S, Genç ZS, Yürüker $S$, Duruksu G, Demircan PC, Sariboyaci AE. Isolation and in vitro characterisation of dental pulp stem cells from natal teeth. Histochem Cell Biol 2010;133:95-112.

48. Ren Z, Wang J, Zhu W, Guan Y, Zou C, Chen Z, Zhang YA. Spontaneous transformation of adult mesenchymal stem cells from cynomolgus macaques in vitro. Exp Cell Res 2011;317:2950-2957.

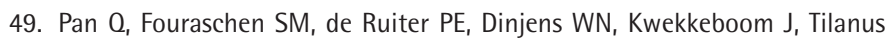
$H W$, van der Laan $\sqcup$. Detection of spontaneous tumorigenic transformation during culture expansion of human mesenchymal stromal cells. Exp Biol Med (Maywood) 2014;239:105-115.

50. He L, Zhao F, Zheng Y, Wan Y, Song J. Loss of interactions between p53 and survivin gene in mesenchymal stem cells after spontaneous transformation in vitro. Int J Biochem Cell Biol 2016;75:74-84.

51. Estrada JC, Albo C, Benguría A, Dopazo A, López-Romero P, CarreraQuintanar L, Roche E, Clemente EP, Enriquez JA, Bernad A, Samper E. Culture of human mesenchymal stem cells at low oxygen tension improves growth and genetic stability by activating glycolysis. Cell Death Differ 2012;19:743-755.

52. Ueyama $H$, Horibe $T$, Hinotsu $S$, Tanaka $T$, Inoue $T$, Urushihara $H$, Kitagawa A, Kawakami K. Chromosomal variability of human mesenchymal stem cells cultured under hypoxic conditions. J Cell Mol Med 2012;16:72-82.

53. Nikitina $V$, Astrelina $T$, Nugis $V$, Ostashkin A, Karaseva T, Dobrovolskaya $E$, Usupzhanova D, Suchkova Y, Lomonosova E, Rodin S, Brunchukov V, LaukDubitskiy S, Brumberg V, Machova A, Kobzeva I, Bushmanov A, Samoilov A. Clonal chromosomal and genomic instability during human multipotent mesenchymal stromal cells long-term culture. PLoS One 2018;13:e0192445.

54. Tarte K, Gaillard J, Lataillade JJ, Fouillard L, Becker M, Mossafa H, Tchirkov A, Rouard H, Henry C, Splingard M, Dulong J, Monnier D, Gourmelon P, Gorin NC, Sensebé L; Société Française de Greffe de Moelle et Thérapie Cellulaire. Clinical-grade production of human mesenchymal stromal cells: occurrence of aneuploidy without transformation. Blood 2010;115:1549-1553.

55. Wang Y, Zhang Z, Chi Y, Zhang Q, Xu F, Yang Z, Meng L, Yang S, Yan S, Mao A, Zhang J, Yang $Y$, Wang $S$, Cui J, Liang $L$, Ji $Y$, Han ZB, Fang $X$, Han ZC. Long-term cultured mesenchymal stem cells frequently develop genomic mutations but do not undergo malignant transformation. Cell Death Dis 2013;4:950

56. Stenderup K, Justesen J, Clausen C, Kassem M. Aging is associated with decreased maximal life span and accelerated senescence of bone marrow stromal cells. Bone 2003;33:919-926.

57. Fu WL, Li J, Chen G, Li O, Tang X, Zhang CH. Mesenchymal stem cells derived from peripheral blood retain their pluripotency, but undergo senescence during long-term culture. Tissue Eng Part C Methods 2015;21:1088-1097.

58. Digirolamo CM, Stokes D, Colter D, Phinney DG, Class R, Prockop DJ. Propagation and senescence of human marrow stromal cells in culture: a simple colony-forming assay identifies samples with the greatest potential to propagate and differentiate. Br J Haematol 1999;107:275-281.

59. Gu Y, Li T, Ding Y, Sun L, Tu T, Zhu W, Hu J, Sun X. Changes in mesenchymal stem cells following long-term culture in vitro. Mol Med Rep 2016;13:52075215.

60. Michalik L, Auwerx J, Berger JP, Chatterjee VK, Glass CK, Gonzalez FJ, Grimaldi PA, Kadowaki T, Lazar MA, O'Rahilly S, Palmer CN, Plutzky J, Reddy JK, Spiegelman BM, Staels B, Wahli W. International Union of 
Pharmacology. LXI. Peroxisome proliferator-activated receptors. Pharmacol Rev 2006;58:726-741.

61. Takada I, Suzawa M, Matsumoto K, Kato S. Suppression of PPAR transactivation switches cell fate of bone marrow stem cells from adipocytes into osteoblasts. Ann N Y Acad Sci 2007;1116:182-195.

62. Weinzierl $K$, Hemprich $A$, Frerich B. Bone engineering with adipose tissue derived stromal cells. J Craniomaxillofac Surg 2006;34:466-471.

63. Safwani WK, Makpol S, Sathapan S, Chua KH. Alteration of gene expression levels during osteogenic induction of human adipose derived stem cells in long-term culture. Cell Tissue Bank 2013;14:289-301.

64. Gozuacik D, Kimchi A. Autophagy as a cell death and tumor suppressor mechanism. Oncogene 2004;23:2891-2906.

65. Kocaturk NM, Akkoc Y, Kig C, Bayraktar O, Gozuacik D, Kutlu 0. Autophagy as a molecular target for cancer treatment. Eur J Pharm Sci 2019;134:116-137.

66. Galluzzi L, Pietrocola F, Bravo-San Pedro JM, Amaravadi RK, Baehrecke EH, Cecconi F, Codogno P, Debnath J, Gewirtz DA, Karantza V, Kimmelman A, Kumar S, Levine B, Maiuri MC, Martin SJ, Penninger J, Piacentini M, Rubinsztein DC, Simon HU, Simonsen A, Thorburn AM, Velasco G, Ryan KM, Kroemer $G$. Autophagy in malignant transformation and cancer progression. EMBO J 2015;34:856-880.

67. Khaminets $A$, Heinrich $T$, Mari $M$, Grumati $P$, Huebner $A K$, Akutsu M, Liebmann L, Stolz A, Nietzsche S, Koch N, Mauthe M, Katona I, Qualmann B, Weis J, Reggiori F, Kurth I, Hübner CA, Dikic I. Regulation of endoplasmic reticulum turnover by selective autophagy. Nature 2015;522:354-358.
68. An H, Harper JW. Systematic analysis of ribophagy in human cells reveals bystander flux during selective autophagy. Nat Cell Biol 2018;20:135143.

69. Onal G, Kutlu O, Gozuacik D, Dokmeci Emre S. Lipid droplets in health and disease. Lipids Health Dis 2017;16:128.

70. Bodnar AG, Ouellette $M$, Frolkis M, Holt SE, Chiu CP, Morin GB, Harley CB, Shay JW, Lichtsteiner $S$, Wright WE. Extension of life-span by introduction of telomerase into normal human cells. Science 1998;279:349-352.

71. Kim J, Kang JW, Park JH, Choi Y, Choi KS, Park KD, Baek DH, Seong SK, Min HK, Kim HS. Biological characterization of long-term cultured human mesenchymal stem cells. Arch Pharm Res 2009;32:117-126.

72. Parsch D, Fellenberg J, Brümmendorf TH, Eschlbeck AM, Richter W. Telomere length and telomerase activity during expansion and differentiation of human mesenchymal stem cells and chondrocytes. J Mol Med (Berl) 2004;82:49-55.

73. Zimmermann S, Voss M, Kaiser S, Kapp U, Waller CF, Martens UM. Lack of telomerase activity in human mesenchymal stem cells. Leukemia 2003;17:1146-1149.

74. Ullah I, Subbarao RB, Rho GJ. Human mesenchymal stem cells - current trends and future prospective. Biosci Rep 2015:35.

75. Zavan B, Giorgi C, Bagnara GP, Vindigni V, Abatangelo G, Cortivo R. Osteogenic and chondrogenic differentiation: comparison of human and rat bone marrow mesenchymal stem cells cultured into polymeric scaffolds. Eur J Histochem 2007;51(Suppl 1):1-8. 